\title{
STABILITAS EDIBLE FILM PATI SAGU (METROXYLON SAGU ROTTB.) ASETAT SELAMA PENYIMPANAN PADA BERBAGAI SUHU
}

\section{STABILITY OF SAGO (METROXYLON SAGU ROTTB.) STARCH ACETATE EDIBLE FILM DURING STORAGE UNDER VARIOUS TEMPERATURES}

\author{
Rosniyati Suwarda ${ }^{1,2)}$, Tun Tedja Irawadi $\left.{ }^{3}\right)^{*}$, Prayoga Suryadarma $^{4}$, Indah Yuliasih ${ }^{4}$ \\ ${ }^{1)}$ Program Studi Teknologi Industri Pertanian, SPs - Institut Pertanian Bogor. \\ ${ }^{2}$ Balai Pengkajian Teknologi Pertanian Maluku. Jl. Chr Soplanit-Rumah Tiga Ambon, Maluku \\ ${ }^{3)}$ Departemen Kimia, Fakultas Matematika dan Ilmu Pengetahuan Alam - IPB \\ E-mail : tun tedja@yahoo.com \\ ${ }^{4)}$ Departemen Teknologi Industri, Fakultas Teknologi Pertanian - IPB \\ Makalah: Diterima 25 April 2019; Diperbaiki 11 November 2019; Disetujui 30 November 2019
}

\begin{abstract}
The degree of stability of starch-based edible films during storage varies greatly compared to synthetic films. This work aimed to study the effect of storage temperatures on the stability of sago starch acetate edible film during storage. Edible films produced by casting and storage at 5, 30 and $40{ }^{\circ} \mathrm{C}$ temperatures for 34 days. The observed characteristics were crystallinity, contact angle, physical, mechanical and barrier (WVTR) film properties. Sago starch acetate edible films presented lower relative crystallinity $(10,10 \%)$ and highest contact angle $\left(51,04^{\circ}\right)$ when compared with native starch edible films. The results indicated that sago starch acetate edible films were relatively stable when stored at low $\left(5^{\circ} \mathrm{C}\right)$ and high $\left(30\right.$ and $\left.40{ }^{\circ} \mathrm{C}\right)$ temperatures. Storage temperatures did not affect physical properties (solubility, transparency) and mechanical (elongation at break / $E A B)$ of sago starch acetate edible films except tensile strength (TS) and water vapor transmission rate (WVTR). $T S$ values increased at temperatures 30 and $40^{\circ} \mathrm{C}$ and $W V T R$ values increased at temperature $30^{\circ} \mathrm{C}$. Changes in physical and mechanical properties occur at the beginning of storage, but then tend to be stable until the end of storage. Sago starch acetate edible films had low physical and mechanical characteristics, that was TS (2.25$4.90 \mathrm{MPa})$, elongation at break (29.65-89.62\%), solubility (15.01-29.61\%), transparency (0.91-1.87) and very low WVTR value (0.07-0.33 g/m².hour) and Ea (-8.6E-04 kJ/mol). Sago starch acetate edible films had good physical and mechanical properties and resistant to moisture, can be used for applications as edible films and coatings for foods that contain high water content.
\end{abstract}

Keywords: edible film, mechanical and physical properties, sago starch acetate, water vapor transmission rate.

\section{ABSTRAK}

Tingkat kestabilan edible film berbasis pati selama penyimpanan sangat bervariasi dibandingkan dengan film sintetis. Tujuan dari penelitian ini adalah mengkaji pengaruh suhu penyimpanan terhadap stabilitas edible film selama penyimpanan. Edible film dicetak (casting) dan disimpan pada suhu 5, 30 dan $40{ }^{\circ} \mathrm{C}$ selama 34 hari. Karakteristik yang diamati adalah kristalinitas, contact angle, sifat fisik, mekanik dan barrier (WVTR) film. Edible film pati sagu asetat menghasilkan kristalinitas rendah $(10,10 \%)$ dan contact angle tinggi $\left(51,04^{\circ}\right)$ bila dibandingkan dengan edible film pati sagu alami. Edible film pati sagu asetat relatif stabil ketika disimpan pada suhu rendah $\left(5^{\circ} \mathrm{C}\right)$ maupun tinggi $\left(30\right.$ dan $\left.40^{\circ} \mathrm{C}\right)$. Suhu penyimpanan tidak mempengaruhi sifat fisik (kekarutan, transparansi) dan mekanis (elongasi at break/EAB) edible film pati sagu asetat kecuali kekuatan tarik (TS) dan laju tansmisi uap air (WVTR). Nilai TS meningkat pada suhu 30 dan $40{ }^{\circ} \mathrm{C}$ dan Nilai WVTR meningkat pada suhu $30^{\circ} \mathrm{C}$. Perubahan sifat fisik dan mekanis terjadi pada awal penyimpan, namun selanjutnya cenderung stabil sampai akhir penyimpanan. Edible film pati sagu asetat memiliki karaktristis sifat fisik dan mekanis yang rendah yaitu, TS (2,25-4,90 MPa), elongasi at break (29,65-89,62\%), kelarutan (15,01-29,61\%), dan transparansi (0,91-1,87). Edible film pati sagu asetat relatif stabil sampai akhir penyimpanan. Edible film pati sagu asetat mempunyai sifat mekanis yang baik dan resisten terhadap uap air, dapat digunakan untuk aplikasi sebagai bahan kemasan terutama pada lingkungan yang lembab.

Kata kunci: edible film, laju transmisi uap air, pati sagu asetat, sifat fisik dan mekanik

\section{PENDAHULUAN}

Pati sagu mempunyai potensi yang besar untuk dieksplorasi dalam pengembangan edible film dan coating karena kelimpahan bahan, mudah diperoleh, harga relatif murah, dapat dimakan (edible), dan mudah di daur ulang (renewable) serta kemudahannya untuk dimodifikasi (versatile compound) secara fisikokimia. Selain itu, komposisi amilosa yang tinggi pada pati sagu yaitu $27 \%$ (Ahmad et al., 1999) memiliki potensi sebagai bahan pembentuk film yang kuat (Rodriguiez et al., 2006). 
Pati dengan kadar amilosa tinggi dapat membentuk sifat lapisan tipis (film) yang sangat baik dibandingkan dengan pati yang kandungan amilosanya rendah (Mali et al., 2005). Film berbasis pati mempunyai sifat penghalang yang tinggi terhadap $\mathrm{O}_{2}$ dan $\mathrm{CO}_{2}$ (Forssell et al., 2002). Namun film berbasis pati seperti pati sagu memiliki sifat penghalang yang rendah terhadap uap air akibat dari sifat hidrofiliknya (Wu et al., 2001; Mali et al., 2005; Karbowiak et al., 2007).

Sifat edible film dan coating berbasis pati secara umum bervariasi tingkat kestabilanya selama waktu penyimpanan dibandingkan dengan film-film sintetis. Variasi ini dapat mempengaruhi fungsi pada makanan yang dilapisi sehingga stabilitas film yang tinggi untuk waktu yang lama umumnya diinginkan. Ketika film atau lapisan terpapar pada kondisi lingkungan tertentu selama waktu penyimpanan, akan mempengaruhi sifat fisik dan kimia. Perubahan kimia, seperti oksidasi kelompok protein sulfhidril dapat menyebabkan degradasi rantai polimer (Micard et al., 2000).

Perubahan fisik termasuk rekristalisasi polimer yang disebabkan oleh migrasi komponen dengan berat molekul rendah seperti plasticizer yang digunakan dalam formulasi film (Anker et al., 2002). Pemanfaatan pati alami sebagai bahan pengemas masih terbatas karena film yang dihasilkan rapuh, menurunnya sifat mekanik pada kondisi lingkungan lembab, kemampuan prosesnya berkurang karena viskositasnya yang tinggi dan ketidak cocokan dengan beberapa pelarut dan polimer (Garcia et al., 2004; Zamudio-Folres et al., 2007). Selain itu sifat hidrofilik edible film berbahan pati menyebabkan rendahnya stabilitas ketika terpapar pada kondisi lingkungan yang berbeda (Galdeano et al., 2009). Untuk meningkatkan karakteristiknya, beberapa modifikasi pati telah dilakukan antara lain dengan proses asetilasi.

Pati modifikasi dapat secara signifikan meningkatkan sifat hidrofobik dan mengubah sifat kimia, fisik, dan reologi. Subtitusi kelompok ester pada polisakarida memungkinkan perubahan sifat hidrofilik dan menghasilkan perubahan signifikan dalam sifat mekanik dan termal (BeMiller dan Whistler, 1984). Pati asetat memiliki beberapa keunggulan sebagai polimer pembentuk film dibandingkan dengan pati alami. Pati asetat jauh lebih hidrofobik daripada pati alami dan telah terbukti memiliki sifat kekuatan tarik yang lebih baik dalam lingkungan berair. Keuntungan lainnya pati asetat meningkatkan kelarutan, swelling power, tingkat kejernihan pasta, resistensi terhadap retogradasi, dan stabilitas freeze-thaw yang tinggi serta memiliki stabilitas penyimpanan dan pemasakan lebih baik dari pati alami serta mudah di cast dalam pembentukan film (Sodhi dan Singh, 2005; Parandoosh dan Hudson, 1993; Agboola et al., 1991).
Sifat fungsional edible film dipengaruhi oleh beberapa faktor yaitu faktor ekstrinsik seperti kelembaban relatif (RH) dan suhu, dan faktor intrinsik seperti komposisi, terutama plasticizer dan biopolimer (Nisperos-Carriedo, 1994). Untuk melihat daya tahan atau kestabilan edible film pati sagu hasil asetilasi maka perlu dilakukan pengujian terhadap edible film tersebut pada suhu yang berbeda dengan kelembaban ruangan atau RH lingkungan dikondisikan pada $75 \%$. Penelitian ini bertujuan untuk mengkaji pengaruh suhu penyimpanan terhadap stabilitas edible film.

\section{METODE PENELITIAN}

\section{Waktu dan Tempat Penelitian}

Penelitian dilakukan mulai Agustus sampai dengan November 2019 di laboratorium Teknologi Industri Pertanian IPB.

\section{Bahan dan Alat}

Bahan baku yang digunakan dalam penelitian ini adalah pati sagu asetat varietas Molat (Metroxylon sagu Rottb.). Bahan-bahan kimia yang digunakan antara lain $\mathrm{H}_{2} \mathrm{SO}_{4}, \mathrm{NaOH}, \mathrm{HCl}, \mathrm{K}_{2} \mathrm{SO} 4$, $\mathrm{NaCl}$, larutan Luff Schoorl, $\mathrm{KI}, \mathrm{Na}_{2} \mathrm{~S}_{2} \mathrm{O}_{3}$, methyl blue, asam asetat, asam asetat anhidrat, etanol, $\mathrm{KOH}$, indicator phenol red, gliserol dan akuades.

Alat-alat yang digunakan antara lain kertas saring, cawan porselin, erlemeyer, tabung reaksi, gelas ukur, gelas piala, termometer, pipet volumetrik, spektrofotometer, timbangan kasar, timbangan analitik, mikroskop polarisasi (Olympus model BHB, Nippon Kogaku, Jepang) dilengkapi dengan kamera (Olympus model C-35 A), hot plate, magnetic stirer, vacuum filter, freezer, penangas, micrometer dan hygrometer, SEM (EVOMA10), Rapid Visco Analyzer (RVA), desikator, centrifuge, water bath, Chun Yen tensile testing Machine, dan contact angle analyzer (Phoenix 300-Touch, Seo Co., Suwon, Korea).

\section{Karakterisasi Pati Sagu dan Edible Film}

Analisis sifat fisikokimia pati sagu dilakukan terhadap pati sagu alami dan pati sagu asetat meliputi kadar air, kadar abu, protein dan lemak mengikuti metode AOAC (2006), kadar pati menggunakan metode Luff Schoorl (AOAC, 1997), kadar Amilosa metode IRRI (AOAC, 1995), warna menggunakan colourimeter untuk mengevaluasi warna visual. Warna ditunjukkan sebagai $L, a$, dan $b$ (berturut-turut untuk luminosity, merah, dan kuning, pada skala Hunter), kristalinitas relatif diamati dengan dengan sinar-X difraktometer XRD dan nilai pH ditentukan secara elektrometris (Sokhey dan Chinnaswamy, 1993).

Analisis sifat fungsional pati sagu alami dan pati sagu asetat meliputi kelarutan dalam air, swelling power, kejernihan pasta, freeze -thaw stability (Perez et al., 1999) dan analisis sifat 
amilografi diukur menggunakan Rapid Visco Analyzer (RVA, Model Tecmaster, Newport Scientific, Australia).

Karakterisasi edible film dilakukan terhadap edible film pati sagu alami dan pati sagu asetat pada awal penyimpanan meliputi kristalinitas relatif diamati dengan dengan sinar-X difraktometer XRD, sudut kontak (contact angle, CA), kuat tarik (tensile strength, TS) dan morfologi permukaan edible film dengan SEM.

\section{Preparasi Pati Sagu Asetat}

Proses asetilasi menggunakan metode Wurzburg (1978). Kondisi proses asetilasi (konsentrasi asam asetat anhidrid, $\mathrm{pH}$ reaksi, waktu reaksi) ditentukan berdasarkan penelitian Suwarda et al. (2019). Prosedur proses asetilasi adalah $50 \mathrm{~g}$ pati sagu dimasukkan ke dalam $75 \mathrm{~mL}$ akuades, campuran tersebut diaduk selama 30 menit menggunakan thermostatic bath pada suhu ruang dengan kecepatan $200 \mathrm{rpm}$. Selanjutnya dilakukan pengaturan $\mathrm{pH}$ sampai nilai tertentu $(8,24)$ dengan penambahan $\mathrm{NaOH} 3 \%$. Setelah 5 menit, asam asetat anhidrid dengan konsentrasi $44 \% \quad(\%, \quad \mathrm{v} / \mathrm{b})$ ditambahkan secara perlahan ke dalam campuran reaksi. $\mathrm{pH}$ campuran dijaga ke kondisi awal dengan penambahan $\mathrm{NaOH} 3 \%$. Reaksi dibiarkan berlangsung sesuai dengan waktu yang diinginkan (60 menit). Reaksi dihentikan dengan penambahan $\mathrm{HCl} 0,5 \mathrm{~N}$ sampai $\mathrm{pH}$ 4,5. Pati sagu terasetilasi kemudian disaring dan dicuci dengan $150 \mathrm{~mL}$ aquades sebanyak 3 kali. Pati dikeringkan pada suhu $40^{\circ} \mathrm{C}$ dan digiling halus hingga 80 mesh. Parameter yang diamati adalah persen asetil dan derajat subtitusi (DS) (Whistler dan Daniel, 1995).

\section{Preparasi Edible Film}

Proses pembuatan edible film menggunakan metode Lopez et al. (2008) dan Parra et al. (2004) yang dimodifikasi Suwarda et al. (2019). Pati sagu 5 $\mathrm{g}$ didispersi dalam $80 \mathrm{~mL}$ aquades, larutan diaduk dengan stirrer selama 15 menit. Pati terdispersi dipanaskan pada suhu $80-85^{\circ} \mathrm{C}$ selama 15 menit sambil diaduk dengan stirrer. Gliserol $(1 \%, \mathrm{~b} / \mathrm{b})$ dan $20 \mathrm{~mL}$ aquades ditambahkan sebagai plasticizer, selanjutnya suspensi tersebut dipanaskan kembali pada suhu $80-85^{\circ} \mathrm{C}$ selama 15 menit. Larutan coating (18 g) dicetak (casting) pada acrylic plates $(\varnothing 8,5 \mathrm{~cm})$ dan dikeringkan pada suhu $40^{\circ} \mathrm{C}$ selama 24 jam.

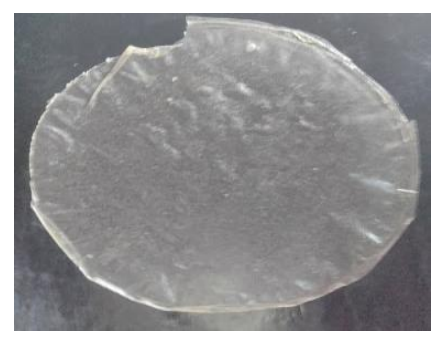

(a)

Gambar 1 Edible film : (a) pati sagu alami dan (b) pati sagu asetat

\section{Uji Stabilitas Spesimen Edible Film}

Spesimen film disimpan dalam desikator pada suhu 5,30 , dan $40^{\circ} \mathrm{C}$ selama 34 hari. $\mathrm{RH}$ dipertahankan konstan pada $75 \%$ dalam setiap desikator dengan menggunakan natrium klorida (NaCl) jenuh (ASTM, 1995). Sampel diamati dan diuji setiap 3 hari sekali untuk mengetahui perubahan sifat fisik dan mekanik yang terjadi selama penyimpanan. Karakterisasi sifat fisik dan mekanik edible film pati sagu asetat selama penyimpanan meliputi, analisis kuat tarik (tensile strength, TS), elongasi (elongation at break, EAB) (ASTM D638, 2005), kelarutan dalam air selama 24 jam (Gontard et al., 1992), laju transmisi uap air (WVTR) (Huri dan Nisa, 2014) transparansi film (Bao et al., 2009) dan sudut kontak (contact angle, CA) (ASTM D5946-04, 2005).

\section{Analisis Statistik}

Data hasil penelitian dianalisis dengan twoway varience ANOVA menggunakan Minitab 18, dengan tingkat kepercayaan $\alpha=0,05$. Faktor perlakuan yang diberikan adalah suhu penyimpanan 5 , 30, dan $40^{\circ} \mathrm{C}$ dan lama waktu penyimpanan selama 34 hari.

\section{HASIL DAN PEMBAHASAN}

\section{Karakterisitik Pati Sagu dan Edible Film}

Bahan baku pembuatan edible film adalah pati sagu asetat dengan karakteristik nilai DS 0,14, warna bubuk pati lebih cerah, kelarutan dalam air pada suhu $70^{\circ} \mathrm{C}$ tinggi, swelling power tinggi, kejernihan pasta tinggi, dan freeze-thaw stability rendah dibandingkan dengan pati alaminya. Karakteristik pati sagu asetat dapat dilihat pada Tabel 1.

Bubuk pati asetat lebih putih yang ditujukkan dengan tingginya nilai $\mathrm{L}$ dan ${ }^{\circ} \mathrm{Hue}$ serta rendahnya nilai chroma. Warna bubuk yang semakin cerah (putih) diperoleh dari proses pemurnian pati asetat yaitu dengan cara menuangkan larutan pati asetat kedalam aquades disertai dengan pengadukan cepat agar bercampur merata atau homogen. Warna bubuk yang putih ini akan berdampak pada transparansi edible film yang tinggi (Gambar 1b) dengan indikasi tingginya kejernihan pasta.

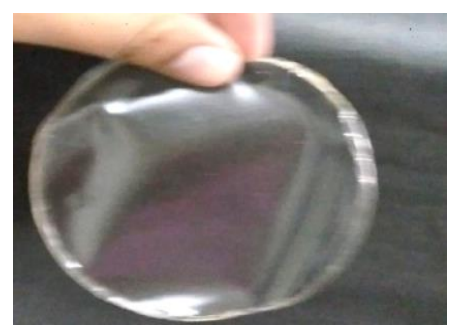


Reaksi asetilasi menyebabkan kandungan amilosa yang lebih rendah dari pati alami. Rendahnya kandungan amilosa pati hasil asetilasi kemungkinan disebabkan karena adanya gugus asetil yang mensubtitusi gugus hidroksil maka kandungan amilosa menjadi menurun. Molekul amylosa terlarut dapat dengan mudah menyesuaikan diri, sehingga gugus hidroksil di sepanjang salah satu rantai cenderung lebih mudah tersubstitusi oleh gugus asetil (Thirathumthavorn dan Charoenrein, 2005).

Tabel 1 menunjukkan sifat fungsional pati sagu hasil asetilasi lebih baik dari pati sagu alami dengan nilai kelarutan dan swelling power yang tinggi. Perubahan nilai freeze-thaw stability yang tidak signifikan. Hal ini disebabkan adanya substitusi gugus asetil yang menggantikan gugus hidroksil sehingga ikatan hidrogen menjadi lemah dan struktur granula pati menjadi kurang rapat, selain itu, menurunya kandungan unsur minor (abu, protein dan lemak). Menurut González dan Perez (2002), adanya gugus asetil dalam pati beras dapat memfasilitasi akses air ke daerah amorf, karena disorganisasi struktur intragranular yang disebabkan oleh efek sterik dan gangguan ikatan hidrogen dalam granula pati. Selanjunya menurut Yuliasih (2008) pati sagu asetat dengan nilai DS $<1,0$ menyebabkan peningkatan kelarutan dan swelling power.
Nilai kelarutan yang tinggi diperlukan dalam pembuatan edible film yang behubungan dengan transparansi film, kelarutan yang rendah menghasilkan edible film pati alami berwarna buram (opaque) (Gambar 1a). Kelarutan juga berhubungan dengan menurunya kandungan amilosa pati asetat. Semakin rendah kandungan amilosa menyebabkan struktur gel yang terbentuk semakin lemah dan menghasilkan padatan terlarut yang lebih besar sehingga kelarutan pati dalam air semakin besar dan menghasilkan kejernihan pasta yang tinggi (Lii dan Chang, 1981; Winarno, 2002).

\section{Kristalinitas}

Hasil analisis kristalinitas pati sagu dengan $X$-Ray Diffraction (XRD) (Gambar 2) menunjukkan bahwa pati sagu alami memiliki puncak pada $17,69^{\circ}$, $16.86^{\circ}, 23,09^{\circ}$ dan pati sagu asetat memiliki puncak pada $17,08^{\circ}, 17,94^{\circ}$ dan $23,09^{\circ}$ (2 teta). Kristalinitas pati alami sebesar $25,83 \%$ dan pati asetat sebesar $20,37 \%$. Hasil tersebut sama dengan yang dilaporkan Ahmad et al. (1999) bahwa pati sagu alami adalah tipe $\mathrm{C}$ yang merupakan gabungan dari tipe $\mathrm{A}$ dan $\mathrm{B}$, untuk tipe A puncak $2 \theta$ berada pada $17^{\circ}, 18^{\circ}$, dan $22^{\circ}, 23^{\circ}, 24^{\circ}$ untuk tipe B.

Tabel 1 Sifat fisikokimia, fungsional pati sagu alami dan pati sagu asetat

\begin{tabular}{lcc}
\hline \multicolumn{1}{c}{ Sifat fisikokimia dan fungsional } & Pati alami $^{\mathbf{1})}$ & Pati asetat $^{\mathbf{2}}$ \\
\hline Kadar air (\% bb) & $11,96 \pm 0,05$ & $11,20 \pm 0,21$ \\
Kadar abu (\% bk) & $0,28 \pm 0,02$ & $0,23 \pm 0,01$ \\
Kadar protein (\% bk) & $0,40 \pm 0,07$ & $0,33 \pm 0,01$ \\
Kadar lemak (\% bk) & $0,41 \pm 0,03$ & $0,15 \pm 0,01$ \\
Kadar amilosa (\%) & $38,79 \pm 0,04$ & $29,56 \pm 0,04$ \\
Kadar asetil (\%) & - & $3.54 \pm 0,25$ \\
Derajat Subtitusi (DS) & - & $0,14 \pm 0,01$ \\
pH & $6,03 \pm 0,82$ & $6,10 \pm 0,57$ \\
Warna : L & $72,71 \pm 3,97$ & $91,64 \pm 0,61$ \\
${ }^{o}$ Hue & $71,43 \pm 3,10$ & $89,07 \pm 1,92$ \\
Chroma & $33,90 \pm 1,52$ & $6,95 \pm 0,18$ \\
Kelarutan pada $70^{\circ} \mathrm{C}$ & $15,44 \pm 1,20$ & $36,70 \pm 0,00$ \\
Swelling power pada $70^{\circ} \mathrm{C}$ & $32,57 \pm 1,90$ & $62,32 \pm 0,96$ \\
Kejernihan pasta $1 \%(\% \mathrm{~T})$ & $62,50 \pm 0,21$ & $76,25 \pm 1,20$ \\
Freeze-thaw stability $(\%$ sineresis $)$ & $79,92 \pm 0,93$ & $75,23 \pm 8,60$ \\
\hline
\end{tabular}

Keterangan : Data rata-rata dua kali ulangan; ${ }^{1)}$ Suwarda et al. (2019); ${ }^{2}$ hasil penelitian ini

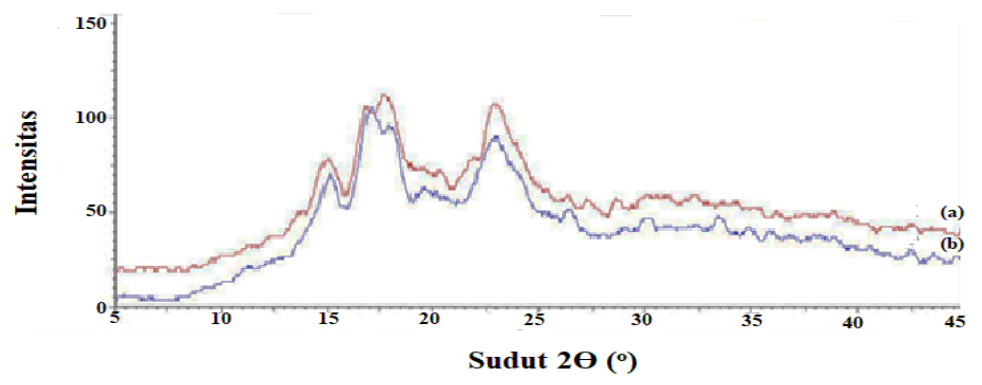

Gambar 2. Pola difraksi sinar X (a) pati sagu alami dan (b) pati sagu asetat 
Pati sagu asetat menunjukkan profil yang sama dengan pati sagu alami, namun muncul puncak yang baru pada $17,94^{\circ}$ ( 2 teta). Adanya puncak baru pada pati asetat menunjukkan bahwa dengan proses esterifikasi, struktur kristal pati alami rusak dan struktur baru pati asetat terbentuk. Beberapa peneliti melaporkan bahwa modifikasi pati dengan asetilasi menurunkan kristalinitas pati dibandingkan dengan pati alaminya, peningkatan persen asetil dan DS menurunkan kritalinitas pati (Rahim et al., 2017; Lopez et al., 2010; Halal et al., 2015; ZamudioFlores et al., 2009).

Hasil analisis kristalinitas edible film dengan XRD (Gambar 3) menunjukkan bahwa edible film pati sagu alami memiliki puncak pada $16.77^{\circ}, 44,44^{\circ}, 64,77^{\circ}$ dan pati sagu asetat memiliki puncak pada $17,01^{\circ}, 44,41^{\circ}$ dan $64,78^{\circ}$ (2 teta). Kristalinitas pati alami sebesar $15,96 \%$ dan pati asetat sebesar $10,10 \%$. Karakteristik edible film pati sagu asetat menunjukkan lebih amorf dari edible film pati sagu alami. Hasil yang sama dilaporkan oleh Talja et al. (2008) bahwa film yang diproduksi dari pati yang mengandung amilosa rendah, medium dan tinggi memiliki puncak $17^{\circ}$ (2 teta) yang menunjukkan bahwa film lebih amorf tetapi masih memiliki kristalit yang kecil. Kristlanitas edible film yang tinggi membuat struktur film lebih rapat sehingga dapat menahan transfer uap air pada film (Singh et al., 2009).

\section{Sudut Kontak (Contact Angle) Edible Film}

Karakteristik sifat hidrofobisitas edible film diukur dengan contact angle (CA). Adanya kelompok asetil setelah modifikasi pati sagu dikonfirmasi dengan hasil pengukuran sudut kontak. Hasil pengukuran contact angle (CA) edible film pati sagu alami dan pati sagu asetat pada awal dan akhir penyimpanan dapat dilihat pada Tabel 2. Dari hasil pengamatan memperlihatkan nilai CA kedua sampel tersebut pada awal hingga akhir penyimpanan tidak mengalami perubahan yang signifikan.

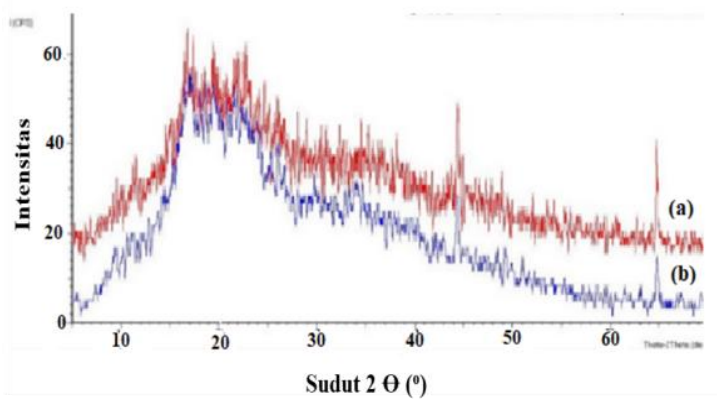

Gambar 3. Pola difraksi sinar X edible film (a) pati sagu alami dan (b) pati sagu asetat

Gambar 4a memperlihatkan nilai CA edible film pati sagu alami rendah $\left(32^{\circ}\right)$ ketika diteteskan dengan air suling cepat menyebar di permukaan edible film, karena permukaan edible film pati sagu alami terdapat banyak makromolekul $\mathrm{OH}$ membentuk ikatan hidrogen dalam air. Peningkatan nilai CA signifikan menjadi $51^{\circ}$ ketika air suling diteteskan pada permukaan edible film pati sagu asetat (Gambar 4b). Penyimpanan pada suhu yang berbeda menyebabkan penurunan nilai $\mathrm{CA}$, namun nilai CA masih diatas $40^{\circ}$, indikasi edible film pati sagu asetat masih bersifat hidrofobik. Menurut Jayaraman et al, (2007) nilai CA 45 sampai dengan 95 ${ }^{\circ}$ menunjukkan permukaan film bersifat hidrofobik. Selanjutnya Jouki et al. (2013) melaporkan bahwa nilai CA antara $30^{\circ}$ dan $90^{\circ}$ menunjukkan permukaan film tidak mudah dibasahi (less wetted).

Tabel 2. Sudut kontak (CA) edible film pati sagu sebelum dan sesudah penyimpanan

\begin{tabular}{cccc}
\hline \multirow{2}{*}{ Hari ke- } & \multirow{2}{*}{ Suhu $\left({ }^{\circ} \mathbf{C}\right)$} & \multicolumn{2}{c}{ CA edible film $\left.\mathbf{(}^{\mathbf{}}\right)$} \\
\cline { 3 - 4 } & Ruang & $32,00 \pm 1,51$ & Pati asetat \\
\hline 0 & 5 & $29,31 \pm 1,84$ & $51,04 \pm 1,21$ \\
34 & 30 & $30,08 \pm 3,49$ & $46,55 \pm 2,13$ \\
& 40 & $30,09 \pm 3,02$ & $44,54 \pm 1,06$ \\
\end{tabular}
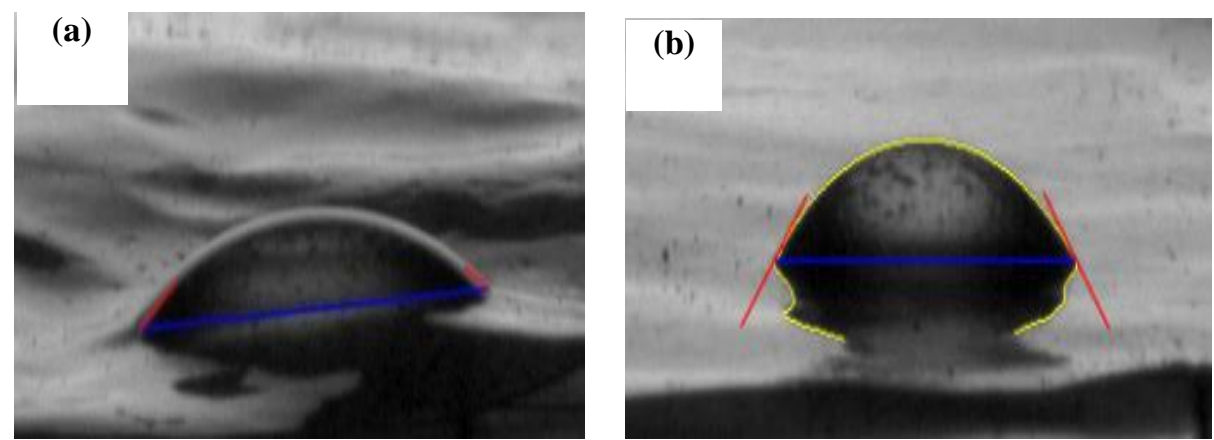

Gambar 4 Sudut kontak pada permukaan edible film : (a) pati sagu alami dan (b) pati sagu asetat 


\section{Morfologi Edible Film}

Pengujian dengan SEM dilakukan untuk melihat hasil mikroskopis permukaan edible film pada perbesaran 100x. Pengujian awal pada morfologi permukaan edible film ditunjukkan pada Gambar 5. Permukaan edible film pati alami terdapat patahan (crak) atau celah pada permukaan sedangkan pati sagu asetat cenderung tidak ada celah dan patahan pada permukaan edible film. Hal ini disebabkan karena perbedaan viskositas pasta dan kelarutan, antara pati sagu alami dan pati sagu asetat, viskositas pati sagu asetat lebih rendah dari pati sagu alami. Viskositas pasta yang tinggi akan berdampak terhadap pembentukan film pada saat di casting karena akan membentuk film yang tebal, tidak rata, permukaan kasar dan mudah rapuh/patah.

\section{Tensile Strength}

Tensile strength (TS) atau kuat tarik merupakan kemampuan penerimaan beban atau gaya. renggang maksimum film sebelum putus Berdasarkan persyaratan bahan kemasan, edible film harus memiliki tingkat ketahanan terhadap retak (crack), ketahanan abrasi dan sifat fleksibel tertentu (Xiao et al., 2011).

Hasil analisis keragaman (ANOVA) ditemukan bahwa interaksi perlakuan suhu dan lama waktu penyimpanan tidak berpengaruh nyata $(\mathrm{P} \geq$ 0,05) terhadap sifat TS edible film pati sagu asetat. Perlakuan faktor tunggal, suhu penyimpanan dan lama waktu penyimpanan berpengaruh nyata $(\mathrm{P}<$
0,05) terhadap sifat TS edible film pati sagu asetat. Hasil analisis TS edible film berkisar antara 2,254,90 MPa. Pengaruh suhu dan lama waktu penyimpanan edible film pati sagu asetat selama penyimpanan dapat dilihat pada Gambar 6

Gambar 6a memperlihatkan penyimpanan pada suhu $5^{\circ} \mathrm{C}$ menghasilkan nilai TS edible film pati sagu asetat lebih rendah dan berbeda nyata dari kedua suhu penyimpanan lainnya (30 dan $40{ }^{\circ} \mathrm{C}$ ). Nilai TS pada suhu $5^{\circ} \mathrm{C}$ tidak berbeda dengan nilai TS edible film pati sagu asetat pada awal penyimpanan $(2,85 \mathrm{MPa})$ ini menunjukkan bahwa edible film pati sagu asetat stabil disimpan pada suhu rendah. Penyimpanan edible film pada suhu 30 dan $40^{\circ} \mathrm{C}$ menghasilkan nilai TS yang tinggi dan tidak berbeda nyata antara keduanya. Hal ini diduga karena terdapat gugus asetil $\left(\mathrm{CH}_{3} \mathrm{COO}\right)$ pada pati asetat sehingga menghambat penyerapan uap air pada edible film menyebabkan kandungan airnya relatif stabil selama penyimpanan pada suhu rendah. Namun kondisi yang berbeda pada penyimpanan suhu yang tinggi, nilai TS edible film pati sagu asetat meningkat. Hal ini diduga karena terjadi penguapan uap air selama penyimpanan sehingga menyebabkan elastisitas menurun dan kuat tariknya (TS) meningkat. Menurut Labuza (1984) pada suhu yang lebih tinggi kandungan air terikat dalam bahan (film) lebih sedikit sehingga mengurangi plastisitas film menyebabkan melemahnya struktur film yang berimplikasi meningkatkan kekuatan tarik serta modulus elastisitas film.

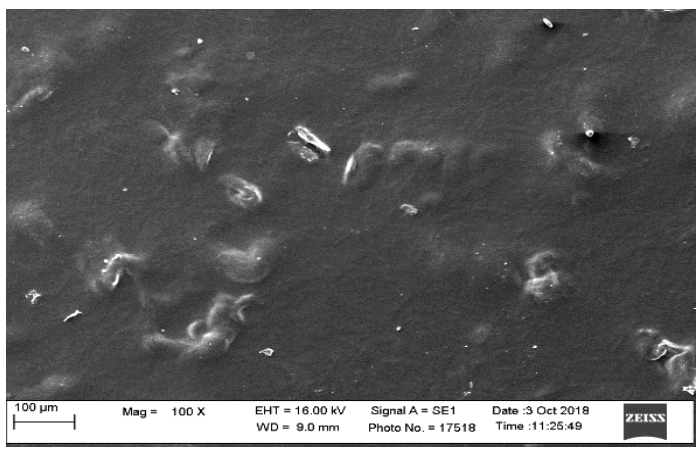

(a)

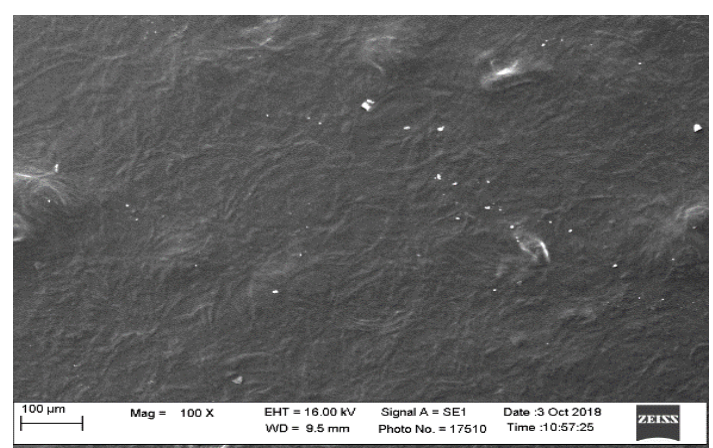

(b)

Gambar 5. Morfologi permukaan edible film: (a) pati sagu alami dan (b)pati sagu asetat dengan SEM perbesaran 100

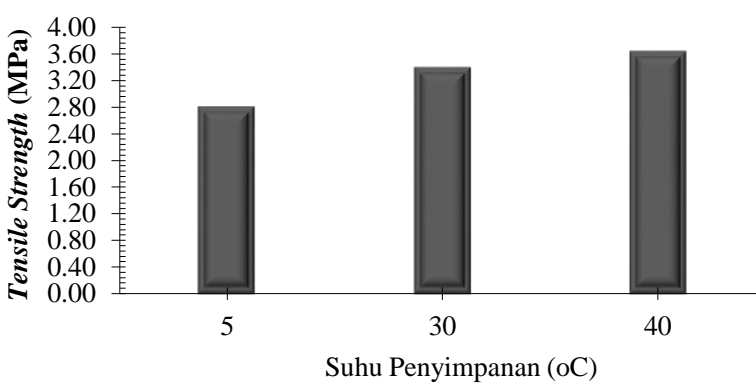

(a)

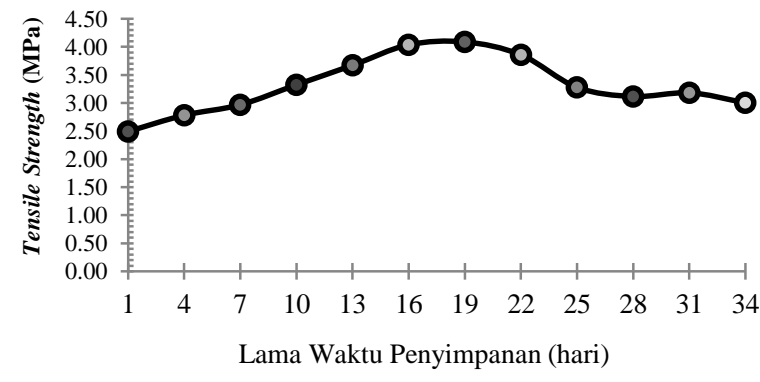

(b)

Gambar 6. Pengaruh suhu (a) dan lama waktu penyimpanan (b) terhadap tensile strength (TS) (MPa) edible film pati sagu asetat 
Gambar 6b memperlihatkan terjadi kecenderungan peningkatan nilai TS edible film pati sagu asetat dan membentuk grafik stasioner dimana nilai TS yang tinggi pada penyimpanan hari ke 16 dan 19, kemudian menurun hingga akhir penyimpanan dan cenderung konstan. Edible film dapat bertahan hingga satu bulan karena nilai TS pada hari ke-34 tidak jauh berbeda pada hari ke-1 bahkan lebih besar. Tingkat kristalinitas edible film pati sagu asetat yang rendah $(10,10 \%)$, membuat edible film semakin elastis. Penurunan daerah kristalin menunjukkan penyusunan struktur rantai yang semakin tidak teratur menyebabkan sifat polimer semakin elastis. Menurut Equistar (2004), polimer yang dengan struktur yang tidak teratur (amorf) memiliki sifat seperti karet dan memiliki sifat fisik plastik yang fleksibel, sedangkan polimer kristalin akan sangat kaku dan keras.

Katili et al. (2013) menyatakan bahwa edible film dengan nilai TS tinggi digunakan untuk produk-produk yang membutuhkan perlindungan tinggi, sementara edible film dengan nilai TS rendah dapat digunakan untuk produk makanan. Nilai TS edible film pati asetat hasil penelitian ini sesuai dengan standar sebagai kemasan untuk produk makanan seperti yang dilaporkan Krochta dan Johnson (1997) yaitu mulai dari $10 \mathrm{kgf} / \mathrm{cm}^{2}$ atau $0,98 \mathrm{MPa}$ dan standar kuat tarik (TS) film yang telah ditetapkan oleh JIS Z 1707 (1997) minimal 0,392 $\mathrm{MPa}$.

\section{Elongation at Break}

Elongation at break (EAB) merupakan persentase perpanjangan putus suatu plastik. Hasil pengujian EAB edible film pati sagu asetat menghasilkan nilai EAB berkisar antara 29,65$89,62 \%$. Berdasarkan hasil ANOVA, perlakuan suhu penyimpanan, interaksi perlakuan suhu dan lama waktu penyimpanan tidak berbeda nyata terhadap nilai EAB $(P \geq 0,05)$. Sedangkan perlakuan lama waktu penyimpanan berpengaruh nyata $(\mathrm{P}<0,05)$ terhadap sifat $\mathrm{EAB}$ edible film pati sagu asetat. Gambar 7 memperlihatkan pengaruh suhu penyimpanan dan lama waktu penyimpanan terhadap nilai EAB.

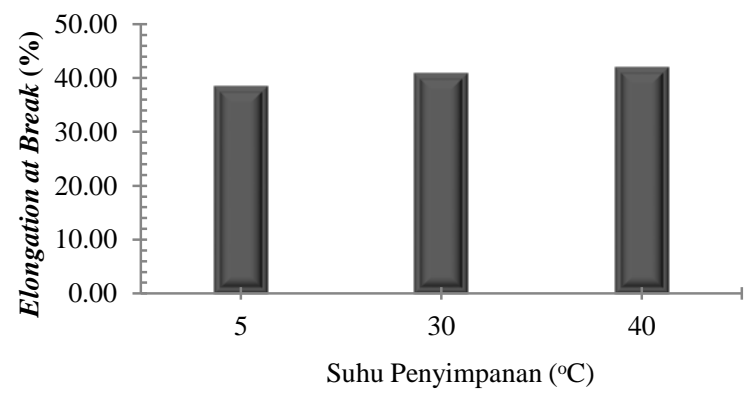

(a)
Gambar 7a menunjukkan bahwa penyimpanan edible film pada suhu yang berbeda ( 5 , 30 dan $40{ }^{\circ} \mathrm{C}$ ) menghasilkan nilai EAB yang yang relatif sama yaitu berturut-turut adalah 38,$48 ; 40,75$ dan $41,95 \%$. Sifat elongasi edible film pati sagu asetat cenderung menurun atau konstan sampai akhir penyimpanan (Gambar 7b). Penurunan nilai EAB edible film pati sagu asetat menunjukkan elastisitas edible film.

Penurunan nilai EAB edible film kemungkinan disebabkan karena pengaruh RH tempat penyimpanan specimen edible film, dari hasil pengamatan pada hari ke-4 RH lingkungan penyimpanan mengalami kenaikan dari hari pertama RH $75 \%$ menjadi $80 \%$, begitu juga yang terjadi pada hari ke-31. RH menyebabkan kelembaban ruang penyimpanan meningkat dan berdampak pada kelenturan edible film. Sifat EAB berkorelasi negatif dengan sifat TS artinya bahwa EAB tinggi maka TS akan menurun, edible film semakin elastis dan tidak mudah putus. Hal ini juga didukung oleh temuan Gennadios et al. (1993) dan Ose's et al. (2009) melaporkan bahwa penurunan TS disebabkan karena peningkatan kelembababan film, kelembaban memiliki efek sebagai pemlastis film seperti film selulosa eter. Pati sagu asetat dengan nilai DS 0.14 dan nilai sudut kontak $51.04^{\circ}$ menghasilkan edible film pati sagu asetat bersifat hidrofobik namun adanya gliserol sebagai plastiziser menyebabkan edible film tersbut masih dapat menyerap air selama penyimpanan karena sifat hidrofiliknya dari gliserol sehingga memberikan efek yang baik terhadap sifat mekanis edible film pati sagu asetat.

\section{Laju Transmisis Uap Air (WVTR)}

Laju transmisi uap air edible film merupakan sifat yang penting untuk diketahui karena dapat memperkirakan daya simpan produk yang dilapisinya. Hasil analisis sidik ragam (ANOVA) ditemukan bahwa perlakuan suhu, lama waktu penyimpanan dan interaksi antara kedua perlakuan berpengaruh nyata $(\mathrm{P}<0,05)$ terhadap sifat WVTR edible film pati sagu asetat.

Gambar 7. Pengaruh suhu (a) dan lama waktu penyimpanan (b) terhadap elongation at break (EAB) \% edible film pati sagu asetat 


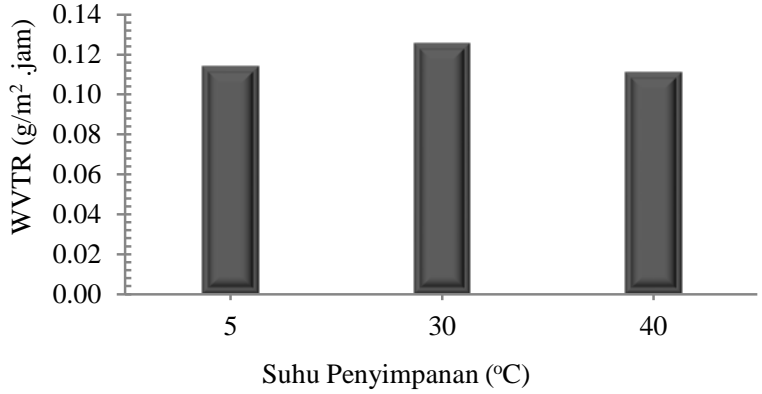

(a)

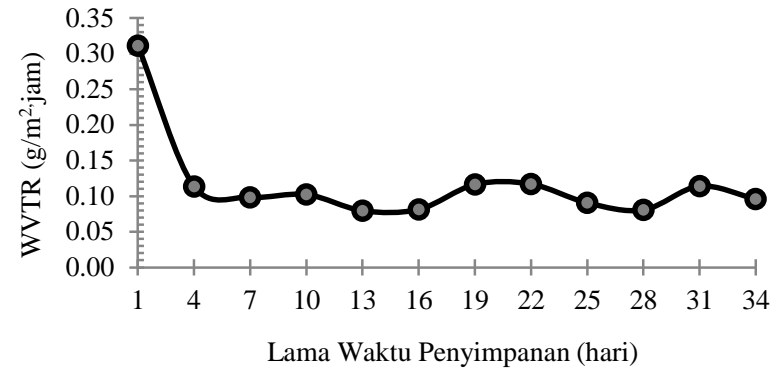

(b)

Gambar 8. Pengaruh suhu (a) dan lama waktu penyimpanan (b) terhadap laju transmisi uap air (WVTR) $\left(\mathrm{g} / \mathrm{m}^{2}\right.$.jam) edible film pati sagu asetat

Gambar 8a memperlihatkan penyimpanan pada suhu $30^{\circ} \mathrm{C}$ menghasilkan nilai WVTR edible film pati sagu asetat berbeda nyata dari kedua suhu penyimpanan lainnya $\left(5\right.$ dan $\left.40^{\circ} \mathrm{C}\right)$. Perbedaan nilai WVTR pada suhu $30^{\circ} \mathrm{C}$ diduga karena meningkatnya kelembaban lingkungan penyimpanan specimen edible film dari RH 75\% menjadi $80 \%$ menyebabkan kondisi lingkungan menjadi lembab dan mendukung transmisi uap air, namun masih menghasilkan nilai WVTR yang rendah yaitu $0,13 \mathrm{~g} / \mathrm{m}^{2}$. Jam dengan perbedaan nilai yang terjadi adalah $0,02 \mathrm{~g} / \mathrm{m}^{2}$.jam. Gambar 8b menunjukkan nilai WVTR edible film pati sagu asetat pada awal penyimpanan lebih besar dan selanjunya menurun sampai akhir penyimpanan dan relatif stabil. Hal ini menunjukkan bahwa edible film pati asetat memiliki sifat barrier yang baik ketika disimpan pada suhu rendah maupun suhu yang tinggi serta dapat bertahan selama 34 hari. Sifat pati asetat yang hidrofobik dapat menahan air atau mengurangi absorbsi air ke dalam matriks. Menurut Krochta (1997), transmisi uap air mudah terjadi pada bagian film yang bersifat hidrofilik. Hidfobisitas edible film ditunjukkan dengan nilai contact angle (CA) pada hari ke-0 dan hari ke-34 berada diatas $40^{\circ}$.

Nilai WVTR juga dapat ditunjukkan dengan hasil uji XRD edible film (Gambar 3), terlihat bahwa edible film pati sagu asetat pada awal penyimpanan menunjukkan tingkat kristalinitas lebih kecil $(10,90 \%)$ dari edible film pati sagu alami, namun rendahnya nilai kristalinitas edible film pati sagu asetat memiliki laju transmisi uap air (WVTR) sangat kecil yaitu berkisar antara $0,07-0,33 \mathrm{~g} / \mathrm{m}^{2}$.jam jika dibandingkan dengan edible film pati alami yaitu $0,66 \mathrm{~g} / \mathrm{m}^{2} . j a m$. Hal ini disebabkan oleh struktur dari edible film pati asetat lebih rapat dan kompak yang ditunjukkan dengan hasil uji SEM (Gambar 5), dari gambar tersebut terlihat permukaan edible film pati sagu asetat pada hari ke-0 lebih halus dan tidak terdapat patahan atau pori sehingga menghambat masuk uap air kedalam edible film yang berimplikasi pada rendahnya nilai WVTR. Nilai WVTR yang rendah menunjukkan bahwa edible film pati sagu asetat mampu menghambat laju uap air masuk kedalam matriks film, sehingga menghambat pertumbuhan jamur atau kapang sampai akhir penyimpanan (34 hari) dan setelah perpanjangan waktu

Penggunaan gliserol 1\% dan konsentrasi pati 5\% menghasilkan nilai WVTR edible film yang sangat sangat rendah. Sifat hidrofilik dari gliserol tidak menyebabkan meningkatnya nilai WVTR baik pada suhu rendah maupun pada suhu tinggi. Hal ini disebakan edible film bersifat hidrofobik dan konsetrasi gliserol yang ditambahkan relatif kecil sehingga sehingga molekul gliserol tidak menyebar merata mengisi rantai polimer pati sagu. Laju transmisi uap air (WVTR) yang rendah dapat digunakan untuk aplikasi luas sebagai bahan kemasan terutama pada lingkungan lembab. Menurut standar yang telah ditetapkan oleh JIS Z 1707 (1997), edible film dapat dikatakan sebagai bahan pengemas pangan apabila laju transmisi uap air yang melewati film tidak lebih dari $7 \mathrm{~g} / \mathrm{m}^{2} / \mathrm{jam}$.

Pengaruh suhu terhadap perubahan nilai WVTR edible film pati asetat selama penyimpanan dievaluasi menggunakan hubungan model Arhenius dengan perasamaan 1 :

$\mathrm{WVTR}=\mathrm{WVTR}_{0} \cdot \exp ^{(-\mathrm{E} / \mathrm{RT})}$ atau

$\ln \mathrm{WVTR}=\ln \mathrm{WVTR}_{0}-\mathrm{Ea} / \mathrm{R} .1 / \mathrm{T}$

dimana WVTR adalah koefisien laju transmisi uap air $\left(\mathrm{g} / \mathrm{m}^{2}\right.$.jam $)$, WVTRo adalah konstan, Ea adalah energi aktivasi $(\mathrm{J} / \mathrm{mol}), \mathrm{R}$ adalah konstanta gas ideal $8,314 \mathrm{~J} / \mathrm{mol}$. K dan T adalah suhu absolut (Kelvin).

Berdasarkan hasil analisis regresi linier suhu penyimpana terhadap WVTR diperoleh persamaan garis lurus yang disajikan pada Gambar 9. Slope persamaan garis tersebut digunakan untuk perhitungan model Arrhenius. Nilai slope (WVTR) diubah menjadi ln (WVTR) (Tabel 3) dihubungkan dengan suhu penyimpanan dalam Kelvin $(\mathrm{K})$ yang diplotkan secara berturut-turut sebagai ordinat dan absis yang ditunjukkan pada Gambar 10 .

Energi aktivasi (Ea) dari proses permeasi ditentukan dari slope logaritma natural dari nilai laju transmisi uap air (WVTR) dengan kebalikan suhu absolut (1/T) seperti yang ditunjukkan pada Gambar 9. Nilai energi aktivasi edible film pati asetat adalah $-8,63 \mathrm{E}-04 \mathrm{~kJ} / \mathrm{mol}$. Nilai energi 
aktivasi (Ea) yang didapat menunjukkan bahwa laju transmisi uap air (WVTR) edible film pati sagu asetat lebih rendah dibandingkan dengan film dari PLA yaitu berkisa atara $-8,9,-10,2$ dan $-8,5 \mathrm{~kJ} / \mathrm{mol}$ dari hasil penelitian Auras et al. (2003). Nilai Ea negatif indikasi bahwa WVTR menurun seiring dengan meningkatnya suhu. Dari Gambar 9 diperoleh model persamaan Arrhenius WVTR yang dapat digunakan untuk memprediksi nilai WVTR dari edible film (Persamaan. 2) pada suhu absolut tertentu (Kelvin).

$\mathrm{WVTR}=0,0024 \cdot \mathrm{e}^{0,1038 \mathrm{x}(1 / \mathrm{T})}$

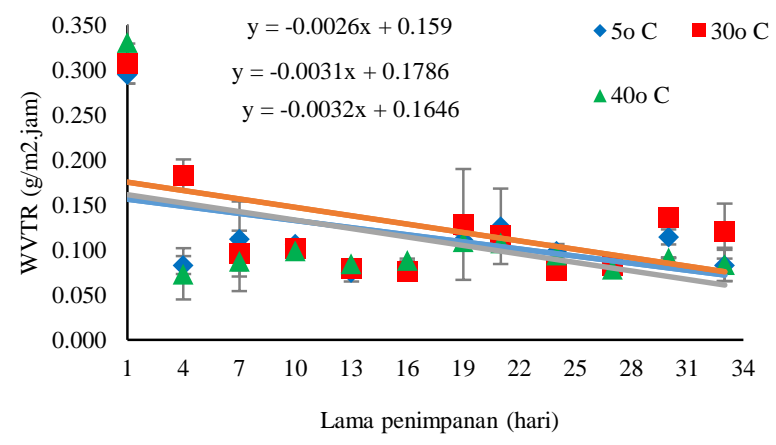

Gambar 9. Pengaruh suhu penyimpanan terhadap laju transmisi uap air (WVTR) $\left(\mathrm{g} / \mathrm{m}^{2} . \mathrm{jam}\right)$ edible film pati sagu asetat

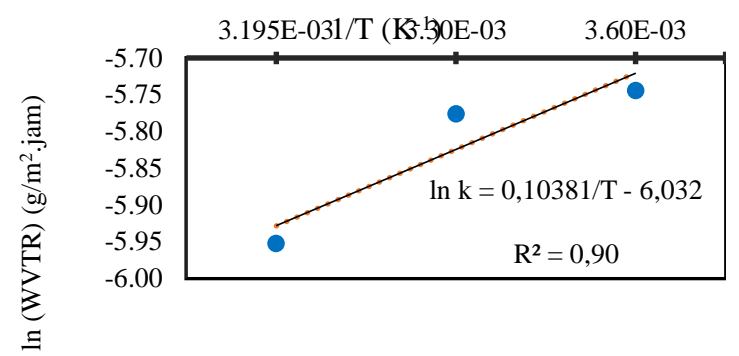

Gambar 10. Grafik hubungan antara laju transmisi uap air (WVTR) dengan suhu (1/T) pada edible film pati sagu asetat

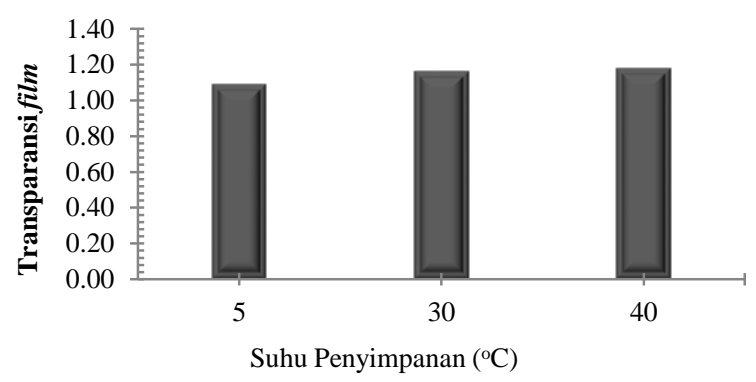

(a)

\section{Transparansi Edible film}

Nilai transparansi film sangat penting pada aplikasi edible film terhadap produk pangan. Transparansi menggambarkan tingkat kejernihan dari film yang dihasilkan. Nilai transparansi yang tinggi atau film yang berwarna bening tidak akan mngubah warna asli dari produk pangan yang dilapisi.

Hasil uji ANOVA ditemukan bahwa perlakuan suhu tidak berpengaruh nyata terhadap transparansi film $(\mathrm{P}>0.05)$, sedangkan perlakuan lama waktu penyimpanan dan interaksi antara kedua perlakuan tersebut berpengaruh nyata $(\mathrm{P}<0.05)$ terhadap nilai transparansi. Grafik pengaruh perlakuan suhu penyimpanan dan lama waktu penyimpanan dapat dilihat pada Gambar 11. Gambar 11a menunjukkan bahwa nilai transparansi edible film yang disimpan pada suhu yang berbeda relatif sama atau tidak berbeda. Namun selama penyimpanan nilai transparan mengalami perubahan dari hari ke-3 dan selanjutnya relatif stabil sampai akhir penyimpanan (Gambar 11).

Hal ini menunjukkan bahwa transparansi film relatif stabil atau tidak mengalami perubahan yang berarti, perubahan nilai transparan selama penyimpanan diduga dipengaruhi ketebalan film. Semakin tebal film, semakin tinggi nilai transparansi karena lebih banyak cahaya diserap pada film yang direkam oleh spektrofotometer dengan panjang gelombang tertentu. Semakin tinggi nilai transparansi semakin buram edible film yang dihasilkan.

\section{Kelarutan}

Kelarutan merupakan sifat fisik edible film yang penting karena berkaitan dengan kemampuan edible film untuk menahan air (Bourbon et al., 2011). Kelarutan yang tinggi menyebabkan edible film mudah larut dalam air dan kemampuannya untuk menahan air menjadi berkurang. Edible film dengan kelarutan tinggi sangat baik digunakan pada produk pangan siap makan karena mudah larut pada saat dikonsumsi (Pitak dan Rakshit, 2011).

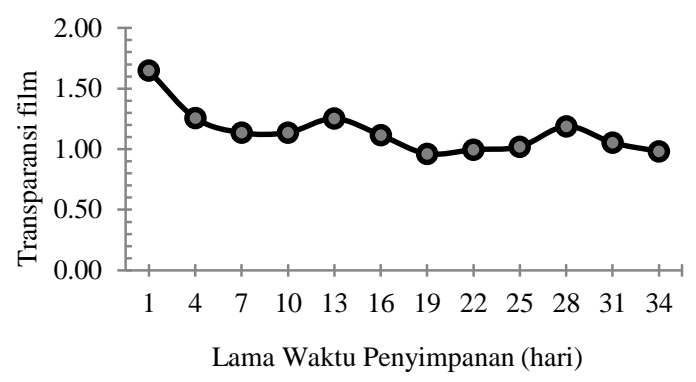

(b)

Gambar 11. Pengaruh suhu (a) dan lama waktu penyimpanan (b) terhadap transpransi edible film selama penyimpanan 


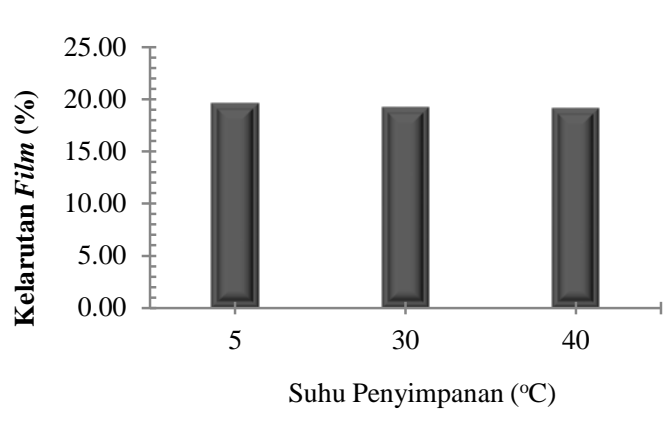

(a)

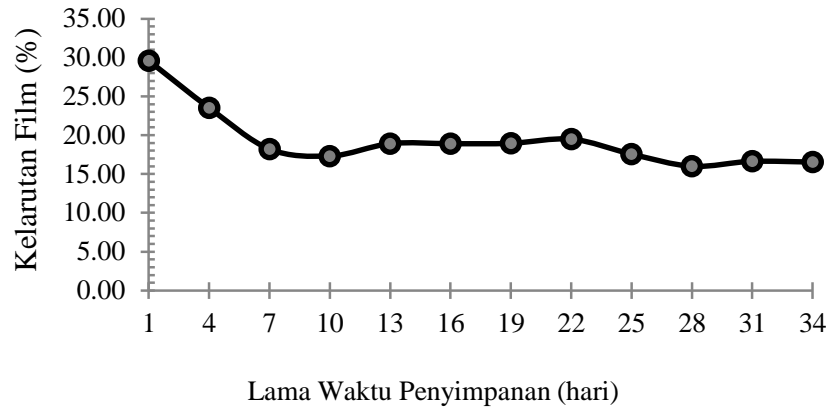

(b)

Gambar 12. Pengaruh suhu (a) dan lama waktu penyimpanan terhadap kelarutan edible film selama penyimpanan

Kelarutan yang tinggi juga berkaitan dengan sifat biodegradasi edible film. Sementara itu, daya larut rendah menjaga integritas struktural misalnya digunakan sebagai bahan coating buah dan sayuran. Kelarutan yang rendah merupakan salah satu persyaratan penting edible film dan coating terutama untuk penggunaan sebagai kemasan pangan yang umumnya memiliki kadar air dan aktivitas air yang tinggi yang berfungsi sebagai pelindung produk pangan (Atef et al., 2015; Singh et al., 2015). Perubahan nilai kelarutan edible film karena perlakuan suhu penyimpanan dan lama penyimpanan ditunjukkan pada Gambar 12.

\section{KESIMPULAN DAN SARAN}

\section{Kesimpulan}

Asetilasi pati sagu menghasilkan sifat fisiskokimia yang lebih baik dari pati alami. Edible film pati sagu asetat lebih lebih transparan, smooth, glossy, tingkat kristalinitas lebih rendah, dan bersifat hidrofobik. Penyimpanan pada suhu 30 dan $40^{\circ} \mathrm{C}$ menyebabkan nilai TS meningkat dan nilai WVTR meningkat pada suhu $30^{\circ} \mathrm{C}$. Sifat hidrofobik dari edible film menyebabkan selama periode penyimpanan 34 hari edible film pati sagu asetat menunjukkan stabilitas terhadap suhu penyimpanan dengan RH ruang penyimpanan sebesar $75 \%$. Perubahan sifat fisik dan mekanis terjadi pada awal penyimpan dimana terjadi penurunan nilai sifat fisik dan mekanis yang signifikan namun selanjutnya cenderung stabil sampai akhir penyimpanan. Edible film pati sagu asetat yang dihasilkan mempunyai sifat mekanis yang baik dan resisten terhadap uap air, dapat digunakan untuk aplikasi sebagai bahan kemasan terutama pada lingkungan lembab.

\section{Saran}

1. Untuk melihat kualitas edible film pati sagu asetat maka masa simpan sampel uji dilakukan lebih dari dua bulan dan melihat stabilitasnya pada penyimpanan suhu beku (dibawah $0^{\circ} \mathrm{C}$ ).

2. Perlu dilakukan aplikasi pada coating bahan pangan seperti buah klimaterik, buah potong, permen dan produk yang mengandung kadar air tinggi.

\section{DAFTAR PUSTAKA}

AOAC, 1995. Official Methods of Analysis of AOAC International, 2v (16 ed.). Arlington, TX: Association of Official Analytical Chemistry.

AOAC. 1997. Official Methods of Analysis. Wahington DC. Association of Official Analytical Chemists Inc

AOAC. 2006. Official Methods of Analysis. Washington (US): Association of Official Analytical Chemists AOAC 1995

ASTM D638. 2005. Standard Test Methods For Tensile Properties of Thin Plastic Sheeting. Philadelphia (US): ASTM

ASTM D5946-04. 2005. Standard Test Method for Corona-Treated Polymer Films Using Water Contact Angle Measurements. Pennsylvania (US): American Society for Testing Material.

Agboola SO, Akingbala JO, and Oguntimein GB. 1991. Physicochemical and functional properties of low DS cassava starch acetates and citrates. Starch, 43: 62-66. doi.org/10.1002/star.19910430207.

Ahmad FA, Williams PA, Doublier J, Durand S, Buleon, A. 1999. Physico-chemical characterization of sago starch. Carbohydr Polym 38: 361-370, doi.org/10.1016/S0144-8617(98)00123-4

Anker M, Berntsen J, Hermansson AM, Stading M. 2002. Improved water vapour barrier of whey protein films by addition of an acetylated monoglyceride. Innovative Food Sci and Emerging Technol 3: 81-92.

Atef M, Rezaei M, Behrooz R. 2015. Characterization of physical, mechanical, and antibacterial properties of agarcellulose bionanocomposite films incorporated with savory essential oil. Food Hydrocolloids. $\quad$ 45: 150-157, doi:10.1016/j.foodhyd. 2014.09.037.

Auras RA, Harte B, Selke S and Hernandez R. 2003. Mechanical, physical and barrier properties 
of polylactide films. Journal of Plastic Film and Sheeting 19:123-135, doi.org/10.1177/8756087903039702.

Bao S, Xu S, and Wang Z. 2009. Antioxidant activity and properties of gelatin films incorporated with tea polyphenol-loaded chitosan nanoparticles. J Sci Food and Agric, $89 \quad$ (15): $2692-2700$, doi.org/10.1002/jsfa.3775.

BeMiller JN dan Whistler RL. 1984. Starch Chemistry and Technology. 2nd ed. London, UK: Academic Press Publications; $879 \mathrm{p}$.

Bourbon AI, Pinheiro AC, Cerqueira MA, Rocha CMR, Avides MC, Quintas MAC, Vicente AA. 2011. Physico-chemical characterization of chitosan-based edible flms incorporating bioactive compounds of different molecular weight. J Food Eng. 106(2):

111-118, doi.org/10.1016/j.jfoodeng.2011.03.024.

Equistar. 2004. A Guide To Polyolefin Film Extrusion. Houston: Lyondell Chemical Company.

Forssell P. 2002. Oxygen permeability of amylose and amylopectin films.Carbohydr Polym, 47(2): 125-129, doi.org/10.1016/S01448617(01)00175-8.

Galdeano MC, Grossmann MVE, Mali S, BelloPerez, La, Garcia Ma, Zamudio-Flores PB. 2009. Effects of production process and plasticizers on stability of films and sheets of oat starch. Materials Sci and Eng : C, 29(2), 492-498, doi:org/ 10.1016/j.msec. 2008.08.031.

García MA, Pinotti M, Zaritzky NM. 2004. Characterization of composite hydrocolloid films. Carbohydr Polym. 56 (3): 339-345.

Gennadios A, Weller, CL and Testin RF. 1993. Property modification of edible wheat gluten-based films. Transactions of the ASAE, 36: 465-470.

Halal SMLE, Colussi R, Pinto, VZ, Bartz J, Radunz M, Carreño NLV, Dias ARG and Zavareze ER. 2015. Structure, morphology and functionality of acetylated and oxidized barley starches. Food Chem 168: 247-256.

Huri D, Nisa FC. 2014. Pengaruh konsentrasi gliserol dan ekstrak ampas kulit apel terhadap karakteristik fisik dan kimia edible film. J Pangan Agroindustri. 2(4): 29-40.

JIS (Japan Industrial Standart). 1997. General Rules of Plastic Films for Food Packaging. Z 1707. Japanese Standart Association

Katili S, BT Harsuno, dan S Irawan 2013. Pengaruh Konsentrasi Plasticizer Gliserol dan Komposisi Khitosan dalam Zat Pelarut terhadap Sifat Fisik Edible film dari Khitosan. Jurnal Teknologi, 6(1): 29-38.
Karbowiak T, Debeaufort F dan Voilley A. 2007. Influence of thermal process onstructure and functional properties of emulsion-based edible films. Food Hydrocolloids, 21: 879888, doi:10.1016/j.foodhyd.2006.07.017

Krochta JM dan DeMulder-Johnston C. 1997. Edible and biodegradable polymerfilms: challenges and opportunities. Food Technol 51(2):61-74.

Lii CY dan Chang SM. 1981. Characterization of red bean (Phaseoulus Radiatus Var. Aurea) starch and its noodle quality. J. Food Sci. 46. Academic Press. London.

López OV, Zaritzky NE, Grossmann MVE, García MA. 2013. Acetylated and native corn starch blend films produced by blown extrusion. J Food Eng. 116(2):286-297.

López O, García M, Zaritzky N. 2008. Film forming capacity of chemically modified corn starches. Carbohydr Polym 73, 573-581.

Lopez OV, Zaritzky NE and Garcia, MA. 2010. Physicochemical characterization of chemically modified corn starches related to rheological behavior, retrogradation and film forming capacity. J Food Eng 100: 160-168.

Mali S, Grossmann, MVE, García MA, Martino MN, Zaritzky NE. 2005. Mechanical and thermal properties of yam starch films. Food Hydrocolloids, 19(1): 157-164. doi.org/10.1016/j.foodhyd.2004.05.002

Micard V, Belamri R, Morel HM, Guilbert. 2000. Properties of chemically and physically treated wheat gluten films. J Agric and Food Chem 48: 2948-2953, doi: 10.1021/jf0001785.

Nisperos-Carriedo MO. 1994. Edible coatings and films based on polysaccharides. In Edible Coatings and Films to Improve Food Quality; Krochta, JM, Baldwin, E. A.; Technomic Publishing Company: Lancaster, pp. 305-335.

Ose's J, Ferna'ndez-Pan I, Mendoza M, Juan I, Mate. 2009. Stability of the mechanical properties of edible films based on whey protein isolate during storage at different relative humidity. Food Hydrocolloids 23:125-131.

Parra D, Tadini C, Ponce P, Lugao A. 2004. Mechanical properties and water vapor transmission in some blends of cassava starch edible films. Carbohydr Polym, 58, 475-481.

Parandoosh S dan Hudson SM. 1993. The acetylation and enzymatic degradation of starch films. J Applied Polym Sci, 48(5): 787-791.

Doi.org/10.1002/app.1993.070480504.

Perez LAB, Acevedo EA, Hernandez LS dan Lopez OP. 1999. Isolation and Partial Characterization of Banana Starches. $J$ Agric Food Chem. 47: 854 - 857

Pitak N dan Rakshit SK. 2011. Physical and antimicrobial properties of banana flour/chitosan biodegradable and self 
sealing films used for preserving fresh-cut vegetables. LWT-Food Science and Technology 44: 2310-2315.

Rahim A dan Kadir S. 2017. The influence degree of substitution on the physicochemical properties of acetylated arenga starches. International Food Research Journal. 102107.

Rodríguez M, Oses J, Sian K, Mate JI. 2006. Combined effect of plasticizer and surfactants on the physical properties of starch based edible films. Food Research International $39 \quad$ : $840-846$, doi.org/10.1016/j.foodres.2006.04.002.

Singh H, Sodhi NS, dan Singh N. 2009. Structure and functional properties of acid thinned sorghum starch. International Journal Food Properties.12(4), $713-725$ doi.org/10.1080/10942910801995614

Sodhi NS dan Singh N. 2005. Characteristics of acetylated starches prepared using starches separated from different rice cultivars. J. Food Eng. 70: 117-127. doi.org/10.1016/j.jfoodeng.2004.09.018

Sokhey AS dan Chinnaswamy R. 1993. Chemical and molecular properties of irradiated starch extrudates. Cereal Chem 70: 260268.

Suwarda R, Irawadi TT, Suryadarma P, Yuliasih I. 2019. Acetylation optimization of sago (Metroxylon sagu rott.) starch for edible film production. International Journal Adv Res. 7(5): 1207-1217.

Talja RA, Peura M, Serimaa R, Jouppila K. 2008. Effect of amylose content on physical and mechanical properties of potato-starchbased edible films. Biomacromolecules, 9(2): 658-663.

Thirathumthavorn D dan Charoenrei S. 2005. Thermal and pasting properties of acidtreated rice starches. Starch/Stärke. 57:217222.
Whistler RL dan Daniel JR. 1995. Carbohydrates. In O. R. Fennema (Ed.), Food Chemistry (pp. 69-137). New York: Marcel Decker.

Winarno FG. 2002. Fisiologi Lepas Panen Produk Hortikultura. Bogor: M-Brio Press..

Wu Y, Weller C, Hamouz F, Cuppett S, Schnepf M. 2001. Moisture loss and lipid oxidation forprecooked ground-beef patties packaged in edible starch-alginate-based composite films. Journal Food Science. 66 (3): 486493 , doi.org/10.1111/j.1365-2621. 2001.tb16137.x

Wurzburg OB. 1978. Starch, modified starch and dextrin. In Products ofthe corn refining industry: Seminar proceedings (pp. 23-32). Washington DC: Corn Refiners Association, Inc.

Xiao G, Zhu, Y, Wang L, You Q, Huo P, and You Y. 2011. Production and Storage of Edible Film Using Gellan Gum, 8 (November), 756-763.

Yuliasih I. 2008. Fraksinasi dan asetilasi pati sagu (metroxylon sagu rottb.) serta aplikasi produknya sebagai bahan campuran plastik sintetik. [Disertasi]. Bogor : Institut Pertanian Bogor.

Zamudio-Flores PB, Bello PL, Vargas TA, Hernández UJ, Romero BC. 2007. Partial characterization of films prepared with oxidized banana starch. Agrociencia. 41 (8): 837-844.

Zamudio-Flores PB, Torres AV, Salgado-Delgado R, Bello-Pe'rez LA. 2009. Influence of the oxidation and acetylation of banana starch on the mechanical and water barrier properties of modified starch and modified starch/chitosanblend films. Journal Applied Polym Science. 115, 991-998. 